\title{
Anticipating the formation of guava seedlings using mini-grafting onto smaller-diameter clonal rootstocks
}

\author{
Mariana Barreto de Souza Arantes ${ }^{1}$, Cláudia Sales Marinho², Raudielle Ferreira dos Santos ${ }^{1}$, \\ Sydney Pereira Galvão ${ }^{3}$, Giuliana Pulitini Vaz ${ }^{4}$, Alexandre Pio Viana ${ }^{5}$ \\ Abstract- The production of grafted seedlings requires longer periods of time. The technique of \\ mini-grafting onto rootstocks previously obtained from herbaceous cuttings can guarantee the \\ genetic fidelity of scion and rootstock and allows grafting onto smaller-diameter stems, accelerating \\ the time required to obtain seedlings. The aim of this study was to anticipate the formation of \\ 'Paluma' guava seedlings grafted onto clonal rootstocks with smaller-diameter stems. Treatments \\ consisted of grafting onto rootstocks with five stem diameter classes. The experimental design was \\ randomised blocks with three replicates and five seedlings per plot. Rootstocks were produced from \\ cuttings of herbaceous branches of mother plants originating from crossing between $P$. guineense \\ and $P$. cattleianum. Mini-grafts were obtained from a clonal 'Paluma' guava mini-garden. Seedlings \\ grafted onto rootstocks with stem diameters from 3.7 to $10.3 \mathrm{~mm}$ presented the same success rate \\ however the greatest seedling vigour was observed when grafted onto larger-diameter rootstocks. \\ Grafting success and seedling height show that mini-grafting onto clonal rootstocks with diameters \\ from 3.7 to $5.5 \mathrm{~mm}$ allows producing seedlings suitable for transplanting 300 days after cutting. \\ Index terms: $P$. guineense $\mathrm{x} P$. cattleianum, early grafting, seedling vigour.

\section{Antecipação da formação da muda de goiabeira utilizando-se da minigarfagem sobre porta-enxertos clonais de menores diâmetros}

\section{Corresponding author: claudia.marinho@uenf.br \\ Received: September 22, 2020 Accepted: January 18, 2021}

Copyright: All the contents of this journal, except where otherwise noted, is licensed under a Creative Commons Attribution License.

\section{(cc) $\mathbf{E Y}$} Resumo - A produção de mudas enxertadas demanda maior período de tempo. A técnica da
minigarfagem sobre porta-enxertos obtidos previamente por estaquia herbácea pode garantir a
fidelidade genética da copa e do porta-enxerto e possibilitar a enxertia em caules de menor diâmetro,
antecipando o período de obtenção dessas mudas. O objetivo deste trabalho foi a antecipação da
formação da muda da goiabeira 'Paluma' enxertada sobre porta-enxertos clonais com caules de
menor diâmetro. Os tratamentos foram constituídos pela enxertia sobre porta-enxertos com cinco
classes de diâmetros do caule. O delineamento experimental adotado foi em blocos casualizados,
com três repetições e cinco mudas por parcela. Os porta-enxertos foram produzidos por estaquia
ang author:
de ramos herbáceos de matrizes oriundas de cruzamento entre P. guineense x P. cattleianum. Os \footnotetext{
hotmail.com (ORCID 0000-0002-4849-7285)
} 


\section{Introduction}

Brazil is the world's fourth largest guava producer. Until the 1980s, guava propagation in the country was carried out by seminiferous route, as it is still performed in countries with expressive guava production such as Pakistan, which is the world's third largest producer (PEREIRA et al., 2017; ALTENDORF, 2018). The search for uniform orchards in Brazil caused vegetative propagation to be adopted and herbaceous cuttings to become the most used propagation technique for obtaining guava seedlings (PEREIRA et al., 2017). However, with the advancement of 'Guava decline', a complex disease caused by Meloidogyne enterolobii nematode and subsequent infection by Neocosmospora falciformis soil fungus (GOMES et al., 2011; CASTRO, 2019; VELOSO et al., 2020), the propagation route of these seedlings has been rethought, as Psidum guajava has high susceptibility to this nematode (CARNEIRO et al., 2001; BIAZATTI et al., 2016). In this context, obtaining seedlings through grafting may become mandatory, since the use of rootstocks resistant to $M$. enterolobii would allow the cultivation of guava trees in already contaminated areas (SOUZA et al., 2018) and studies aimed at the selection of interspecific hybrids with resistance genes for the phytonematode and genes that express rootstock compatibility with commercial guava scions have been carried out (COSTA et al., 2012; GOMES et al., 2017).

The availability of grafted seedlings is still limited for guava due to the degree of difficulty of execution and the longer time required to obtain them, with minimum period of fourteen months, when rootstock is obtained by the seminiferous route (ROBAINA et al., 2015), while guava seedlings multiplied by herbaceous cuttings are obtained in less than six months (COSTA; COSTA, 2003). In order to obtain seedlings grafted onto rootstocks compatible with guava and resistant to the nematode, rootstock propagation would also need to be asexually performed.

Mini-grafting can be used as alternative to reduce the time for obtaining grafted guava seedlings (CAMPOS et al., 2017) and this technique also allows the use of smaller-diameter rootstocks.

Campos et al. (2017) used the mini-grafting technique and obtained the formation of grafted seedlings in shorter time, around 350 days, using rootstocks with diameter of $3.5 \mathrm{~mm}$ previously obtained by seminiferous propagation.

$P$. guineense $\mathrm{x} P$. catleianum hybrids have been reported to be resistant to $M$. enterolobii (GOMES et al., 2017). However, it is still necessary to evaluate its grafting compatibility with guava. The reduction in the time for the production of these seedlings could be achieved through mini-grafting on smaller-diameter clonal rootstocks.
The aim of this work was to evaluate the technical feasibility of mini-grafting onto rootstocks previously cloned by herbaceous cuttings and with different stem diameters, aiming at anticipating the formation of 'Paluma' guava grafted seedlings.

\section{Material and methods}

Mother plants were composed of shrubs of three genotypes kept in 50-L pots under screen. These plants are half-sisters and came from seeds obtained by crossing between $P$. guineense and P. cattleianum (GOMES et al., 2017). Collections of herbaceous cuttings were carried out at three times to multiply the material. Rootstocks were composed of a mixture of clones of these three genotypes, distributed into five diameter classes. The criterion for distribution between diameter classes followed the age of rootstocks that were cut between June and October 2018. Rootstocks cut in October, for example, were thinner and younger. All steps for seedling production are illustrated in Figure 1.

The collection of sprouts from mother plants was carried out according to methodology described by Biazatti et al. (2018) for the confection of herbaceous cuttings. Cuttings were prepared with two pairs of leaves, from which the basal pair was removed and in the other pair, the limbus was cut in half. Cuttings had the base immersed for 10 seconds in IBA (indolbutyric acid) at concentration of $1500 \mathrm{mg} \mathrm{L}^{-1}$ (FERREIRA et al., 2013). Cuttings were inserted in tubes of $280 \mathrm{~cm}^{3}$ containing commercial Basaplant ${ }^{\circledR}$ substrate and then were taken to moist chamber (Figure 1A), equipped with Fogger-type sprayers and timer to adjust the spray interval every 10 minutes and duration of 15 seconds, with flow of $7 \mathrm{~L} \mathrm{~h}^{-1}$, under pressure of $4.0 \mathrm{kgf} \mathrm{cm}^{-2}$. Cuttings remained in this environment for about 60 days until rooting. Cutting was performed in three months (June, August and October).

After the rooting period, seedlings were acclimated, and the material was removed from the moist chamber and taken to another environment in greenhouse covered with Sombrite ${ }^{\circledR} 70 \%$. Under these conditions, seedlings were irrigated twice a day with fine sieve watering can for 30 days. After this period, rootstocks were transplanted into conical pots with height of $30 \mathrm{~cm}$ and volume of 4.8 $\mathrm{dm}^{3}$ (Figure 1B), filled with Basaplant ${ }^{\circledR}$ substrate for vegetables. The substrate was mixed and homogenized with $9.7 \mathrm{~g} \mathrm{~L}^{-1}$ of simple superphosphate, $30 \mathrm{~g} \mathrm{~L}^{-1}$ of limestone and $6.6 \mathrm{~g} \mathrm{~L}^{-1}$ of Osmocote ${ }^{\circledR}$ slow-release fertilizer in 17-07-12 formulation, and cover fertilization with $7.6 \mathrm{~g}$ of urea, $24.7 \mathrm{~g}$ of simple superphosphate and $2.8 \mathrm{~g}$ of potassium chloride per pot, in three plots, with interval of 30 days. Fortnightly, seedlings received foliar applications with Viçosa mixture containing $25 \mathrm{~g}$ of copper sulphate; $25 \mathrm{~g}$ of quicklime; $40 \mathrm{~g}$ of manganese sulphate; $10 \mathrm{~g}$ of zinc sulphate; $5 \mathrm{~g}$ of boric acid, every $5 \mathrm{~L}$ of water. 
Rootstocks were conducted on a single stem for subsequent grafting with 'Paluma' guava using the minigrafting method proposed by Campos et al. (2017). By the aforementioned method, the scion is grafted with mini-grafts, which come from herbaceous sprouts of clonal mini-garden. The stem diameters of rootstocks were measured at height of $15 \mathrm{~cm}$ from the seedling stem diameter ratio and these were separated into five diameter classes: from 3.68 to $5.5 \mathrm{~mm}$ (class 1); from 5.51 to $6.50 \mathrm{~mm}$ (class 2); from 6.51 to $7.21 \mathrm{~mm}$ (class 3); from 7.23 to $7.74 \mathrm{~mm}$ (class 4) and from 7.75 to 10.32 (class 5). Rootstocks had between $0.62 \mathrm{~m}$ and $1.79 \mathrm{~m}$ in height before grafting (Figure 1C) and were pruned so that grafting could be performed. At that time, plants aged 180-240 days after cutting, and plants of 180 days were those with the smallest diameter. The experimental design used was in RBD, with five treatments (diameter classes), three blocks and five plants per plot.

Mini-grafts were collected from mini-clumps of 'Paluma' cultivar with five years of age. Plants in this mini-garden were pruned 30 days before mini-grafting, so that the stimulus for the emission of new sprouts would occur (Figure 1D). Mini-clumps received the same cover fertilization as plants selected to be used as rootstocks.

The type of grafting adopted was top half-cleft grafting, a technique adapted for grafts that in general have smaller diameters compared to the rootstock (HARTMANN et al., 2013). To perform the grafting, young sprouts were collected and mini-grafts were prepared with two pairs of leaves that had their apical portions cut in half and basal leaves removed to reduce transpiration and dehydration. After preparing mini-grafts, each plant used as rootstock was pruned about $30 \mathrm{~cm}$ above the stem, so that grafting could be performed.

Rootstocks were prepared by removing lower leaves and, after topping, mini-grafts were introduced onto the top of the rootstock. The base of the mini-graft was cut into a bevel, adjusted more on the side of the top and the bandage was performed with Parafilm ${ }^{\circledR}$ (Figure $1 F)$. In order for mini-grafts to remain fixed, the grafting region was wrapped with flexible wire. Subsequently, seedlings were taken to the intermittent moist chamber, since herbaceous mini-grafts are very susceptible to dehydration (Figure 1E).

The moist system was composed of Fogger ${ }^{\circledR}$ type micro-sprayers with interval of 10 minutes and duration of 30 seconds for a period of 60 days. Acclimatization started in the moist chamber when the interval between spray applications was increased to 20 minutes and the spray duration was increased to 30 seconds, with plants being kept under these conditions for five days. After this period, the spraying regime was again modified to 30 -minute intervals with 30-second spray duration for another five days. After this period, seedlings were removed from the moist chamber and taken to a new location in the same greenhouse covered with $70 \%$ sombrite ${ }^{\circledR}(1 \mathrm{G})$, where seedlings were manually irrigated between 10:00 am and 12:00 pm. In this phase, the flexible wire used to wrap the grafting region was removed and seedlings were conducted on a single stem (Figure $1 \mathrm{H}$; 1I).

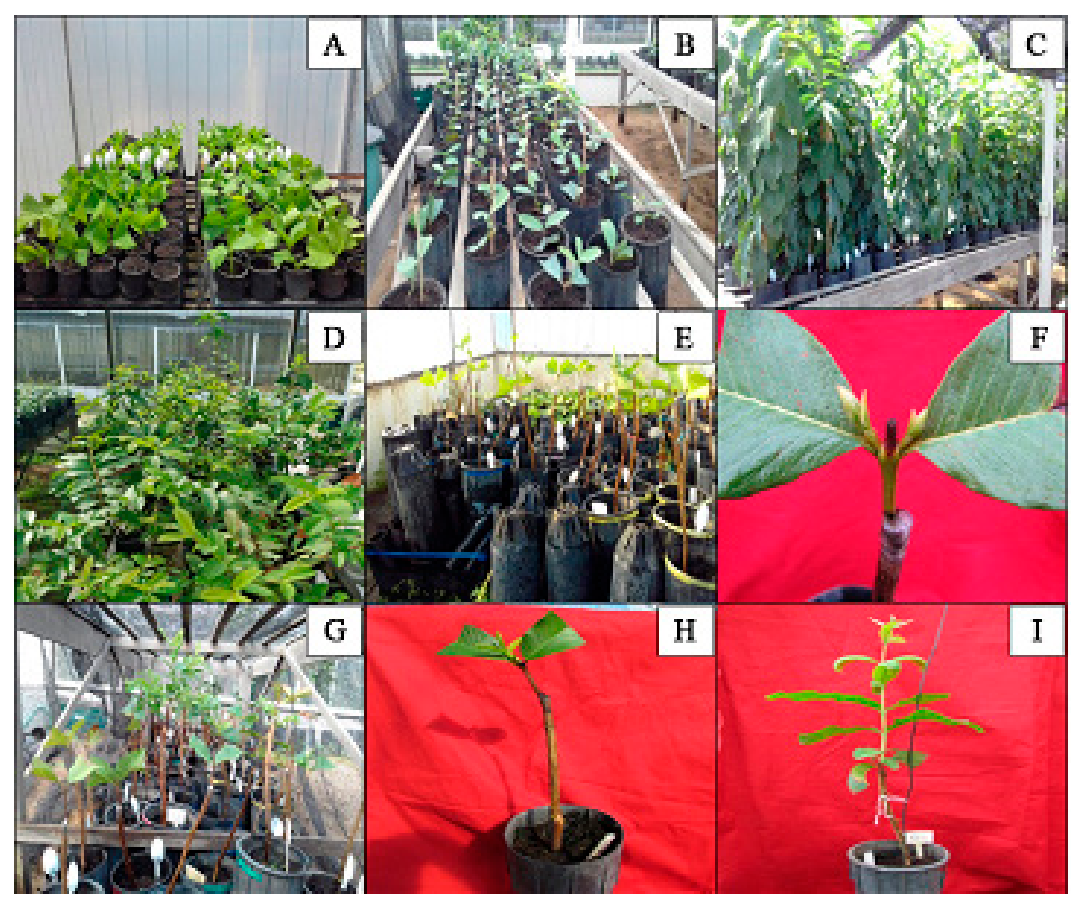

Figure 1. Rooting of rootstocks inside the moist chamber (A); rootstocks transplanted after 60 days of rooting and 30 days of acclimatization (B); rootstock the day before grafting (C); mini-garden of 'Paluma' cultivar used to collect mini-grafts (D); Newly grafted seedlings inside the moist chamber (E); Beginning of mini-graft sprouting (F); Acclimation of grafted seedlings $(\mathrm{G})$; Conduction of grafted seedlings on a single stem (H); Seedling grafted at 300 days after rootstock cutting and 120 days after grafting (I). 
The averages of maximum and minimum temperatures inside the moist chamber were $31^{\circ} \mathrm{C}$ and $27^{\circ} \mathrm{C}$, respectively, for about 60 days. The averages of maximum and minimum relative humidity inside the moist chamber in this period were $98 \%$ and $87 \%$, respectively. During the cultivation of these seedlings, the averages of maximum and minimum temperatures were $32.8^{\circ} \mathrm{C}$ and $20.3^{\circ} \mathrm{C}$ and the maximum and minimum relative humidity values were $94 \%$ and $62 \%$, respectively.

Graft survival was evaluated at 30, 60, 90 and 120 days after grafting. Grafting success was observed at 90 days after grafting. Scion stem and rootstock diameters were measured at three points, $3 \mathrm{~cm}$ above and below the grafting region and in the region of the grafting point with the aid of digital caliper. Seedling diameter and height were evaluated at 90,120,150, 180 and 210 days after grafting. The minimum pattern of seedling suitable for planting was found at 120 days after grafting (Figure 1I). Data regarding grafting success $(\%)$ were transformed according to the arc sine equation $(\mathrm{x} / 100) 1 / 2$ and submitted to analysis of variance. Data from evaluations performed at different times were evaluated in a split-time scheme, with averages between treatments and times submitted to regression analyzes and when these were significant at $5 \%$ probability, the best fit equations were chosen. The statistical software used was SANEST (ZONTA; MACHADO, 1984).

\section{Results and discussion}

At 90 days after grafting, seedling survival stability was reached, which was evaluated at 120 days (Table 1) and the grafting success was verified. At that time, no effect of rootstock diameter on the grafting success was observed, which was, on average, $62.6 \%$.

Robaina et al. (2015) used P. guajava rootstock with average of $8.4 \mathrm{~mm}$ in diameter and obtained grafting success of $65 \%$ at 160 days after grafting by top cleft grafting.

Table 1. Success rate of seedlings (\%) grafted onto rootstock from the $P$. guineense $\mathrm{x} P$. cattleianum crossing. Treatments consisted of five rootstock stem diameter classes: 3.68 to 5.5 (Class 1); 5.51 to 6.50 (Class 2); 6.51 to 7.21 (Class 3) 7.23 to 7.74 (Class 4 ) and 7.75 to 10.32 (Class 5).

\begin{tabular}{ccccc}
\hline $\begin{array}{c}\text { Treatment } \\
\text { Diameter }(\mathrm{mm})\end{array}$ & $\begin{array}{c}\text { Success rate } \\
\text { 30 days (\%) }\end{array}$ & $\begin{array}{c}\text { Success rate 60 } \\
\text { days }(\%)\end{array}$ & $\begin{array}{c}\text { Success rate } \\
90 \\
\text { days }(\%)\end{array}$ & $\begin{array}{c}\text { Success rate 120 } \\
\text { days }(\%)\end{array}$ \\
\hline Class 1 & 86.67 & 80.00 & 73.33 & 73.33 \\
Class 2 & 86.67 & 80.00 & 60.00 & 60.00 \\
Class 3 & 86.67 & 60.00 & 53.33 & 53.33 \\
Class 4 & 80.00 & 80.00 & 66.66 & 66.66 \\
Class 5 & 86.67 & 80.00 & 60.00 & 60.00 \\
\hline CV (\%) & 21.82 & 23.54 & 43.21 & 43.21 \\
\hline Significance & n.s. & n.s. & n.s. & n.s. \\
\hline
\end{tabular}

Not significant by $\mathrm{F}$ test at $5 \%$ probability (n.s.)

Some authors have observed that the use of smaller stem diameters for rootstocks does not compromise grafting success, confirming the results of the present study. Campos et al. (2017) used rootstocks obtained by seminiferous propagation of guava with diameters close to $3.5 \mathrm{~mm}$ and observed $84 \%$ grafting success for 'Paluma' guava seedlings and $54 \%$ for 'Cortibel 1 ' guava seedlings, demonstrating that under the same conditions and grafting technique, there are grafting success variations between different genetic materials both in the scion and in the rootstock. Thus, the grafting success obtained in this work $(62.6 \%)$ can be considered satisfactory, since genetic materials are different.

Abbas et al. (2013) grafted 'Gola' cultivar, widespread in Pakistan, by grafting on guava rootstocks from seeds. The technique was directly performed in the field and the rootstock was as thick as a pencil at the time of the procedure. The authors observed that there was about $7.5 \%$ grafting success. On the other hand, Singh et al. (2007) found that when 'Allahabad Safeda' and 'Sardar' guava cultivars were grafted onto rootstocks of sexual origin presenting between $5 \mathrm{~mm}$ and $10 \mathrm{~mm}$ in diameter, seedlings had results above $80 \%$ grafting success when the procedure was carried out in greenhouse, indicating that protected environments favour the guava grafting success.

Seedling height was influenced by the interaction between rootstock diameter and time of evaluation (Figure 2A). At 120 days after grafting, seedlings reached between 44 and $60 \mathrm{~cm}$ in height, all considered suitable for planting. At 210 days after grafting, seedling height responded linearly to the increase in rootstock diameter (Figure 2B). Larger rootstocks provided greater height growth. 

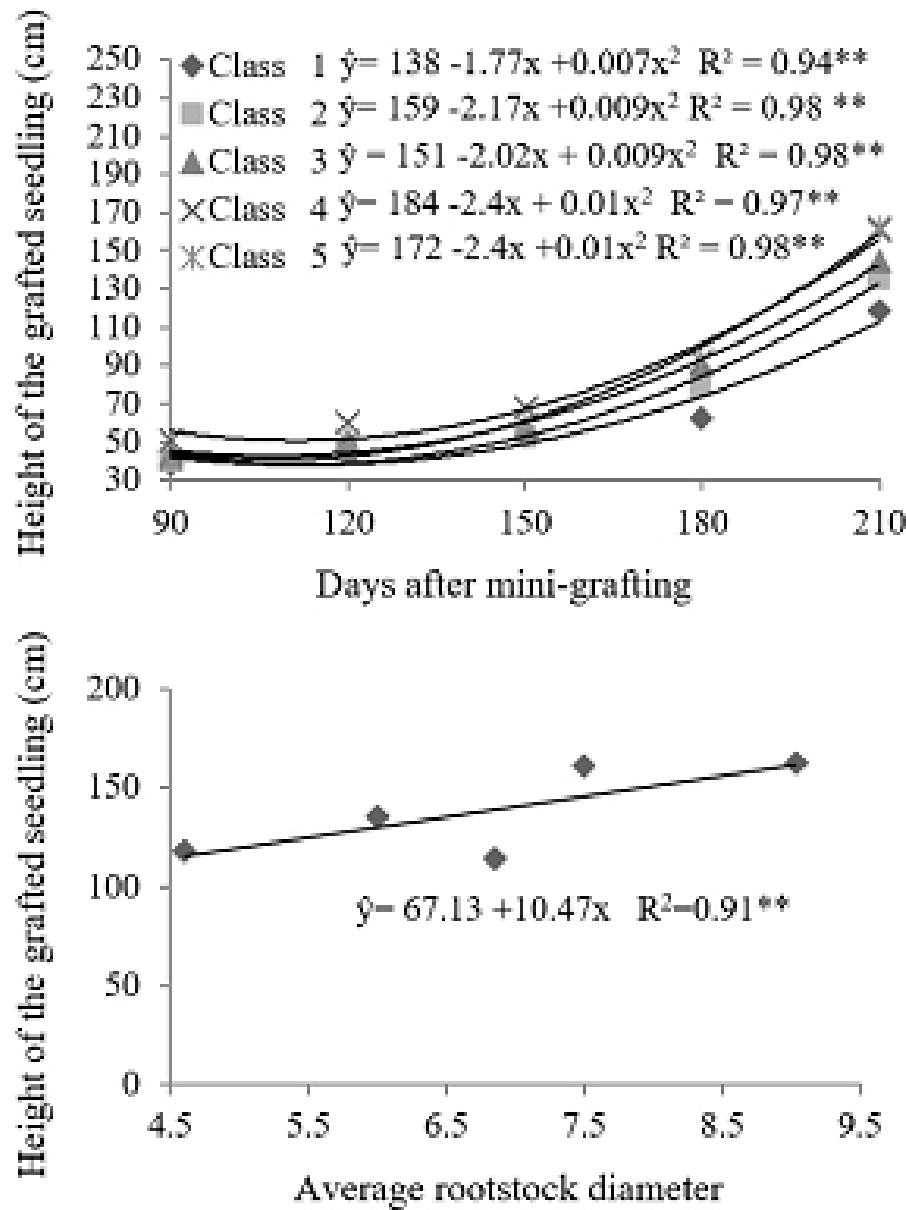

Figure 2. Polynomial regressions for the height of 'Paluma' guava seedlings grafted by mini-grafting onto rootstocks of different diameter classes evaluated between 90 and 210 days after grafting (A). Polynomial regression for average height of 'Paluma' guava seedlings grafted by mini- grafting as a function of the average rootstock diameter $(\mathrm{mm})$ (B). **Significant at $1 \%$ probability. Rootstock diameter classes at the time of grafting: 1 (3.68 to $5.5 \mathrm{~mm}$ ); 2 (5.51 to $6.5 \mathrm{~mm}) ; 3$ (6.51 to $7.22 \mathrm{~mm}) ; 4$ (7.23 to $7.74 \mathrm{~mm}$ ) and 5 (7.75 to $10.32 \mathrm{~mm}$ ).

It has been observed that the use of different rootstock diameters is important, as this difference can influence seedling vigour and growth (SHARMA et al., 2019). In this sense, the use of rootstocks between $8 \mathrm{~mm}$ and $10 \mathrm{~mm}$ in diameter is recommended for the performance of grafting by top cleft grafting (COSTA; COSTA, 2003; ROBAINA et al., 2015). More vigorous rootstock provides increase in the transport of water and nutrients and in this sense, the tendency of seedling shoots is to show greater growth (SOMKUWAR et al., 2015; SHARMA et al., 2019). However, the production of more vigorous guava rootstocks requires prolonged time, around 280 days (ROBAINA, 2011).

Costa and Costa (2003) reported that guava seedlings produced by grafting must have between 40 and $60 \mathrm{~cm}$ in height and are usually obtained with this pattern in a period from 540 to 780 days after rootstock sowing and grafting by top cleft grafting. However, Campos et al. (2017) used $P$. guineense rootstock, compatible with 'Paluma' guava, obtained by seminiferous route with average diameter of $3.5 \mathrm{~mm}$, at 200 days after sowing, for mini-grafting of scions of 'Paluma' and 'Cortibel 1' cultivars. In this work, the authors obtained, 350 days after rootstock sowing, seedlings that reached $50.9 \mathrm{~cm}$ and 40 $\mathrm{cm}$ in height, respectively, for 'Paluma' and 'Cortibel 1' cultivars.

In the present study, the thinnest rootstocks were obtained 180 days after cutting, which is less time than that observed in previously mentioned works. After grafting by mini-grafting with 'Paluma' guava, seedlings reached height close to that necessary for planting at 120 days after grafting (Figure $2 \mathrm{~A}$ ). When counting the time required for grafting and the time elapsed from grafting to seedling formation, it was observed that plants were able for planting from 300 days after cutting. Seedlings grafted onto thicker rootstock had greater height, indicating the possibility of better performance after planting. 
The differences between stem diameter classes of rootstocks remained after mini-grafting, with reduction in these differences between 90 and 210 days after minigrafting (Figure 3A). This reduction in the difference between stem diameters of grafted seedlings was provided by the higher growth rate of smaller-diameter rootstocks. Although smaller-diameter rootstocks provide greater growth speed for the grafted seedling, at 180 days after mini-grafting, the most vigorous rootstock provided greater development in plant stem diameter (Figure 3B).
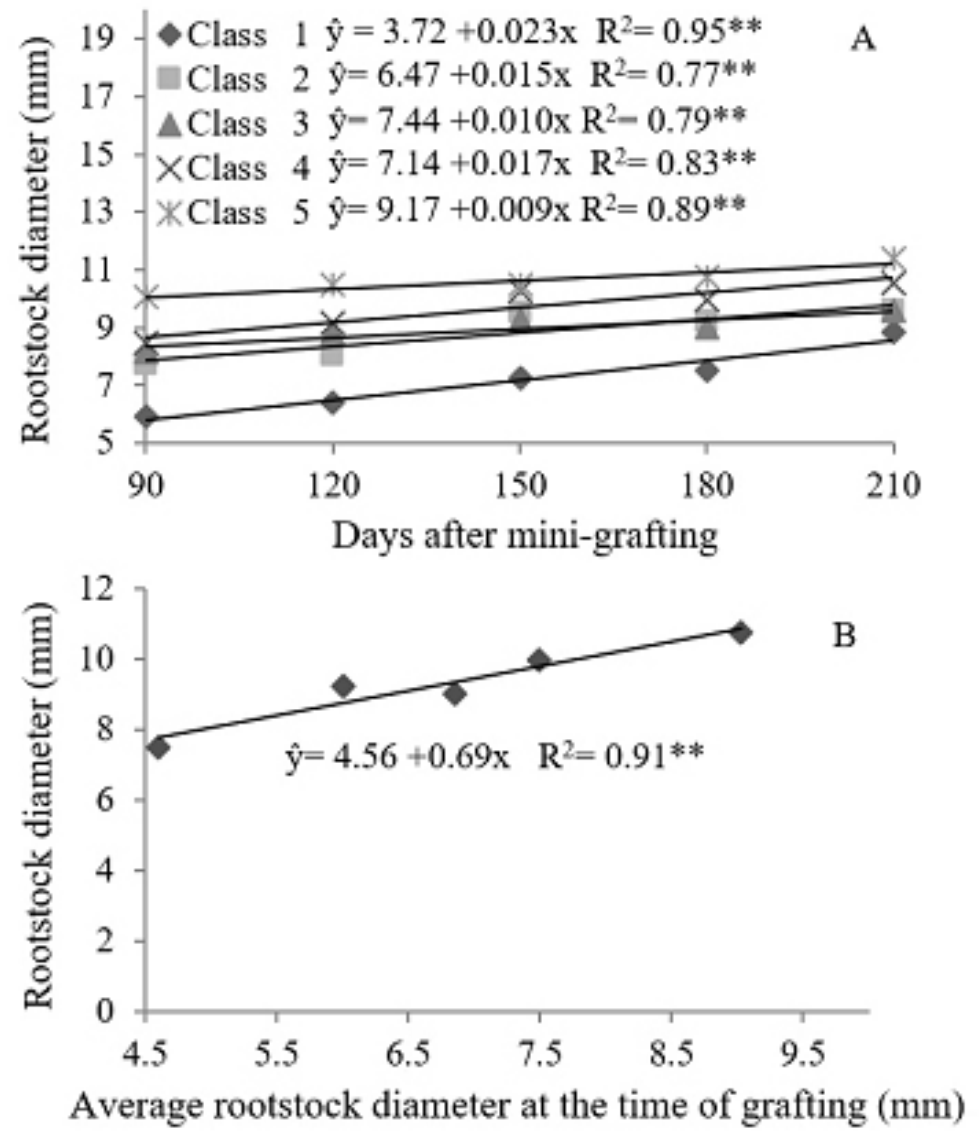

Figure 3. Polynomial regression for the average rootstock diameter between 90 and 210 days after grafting 'Paluma' guava by mini-grafting (A). Polynomial regression for the seedling stem diameter below the grafting region as a function of rootstock diameter at the time of grafting (B). ** Significant at $1 \%$ probability.

The possibility of using smaller-diameter rootstocks varies according to the species, because depending on the species, the lower rootstock vigour may impair grafting or result in inadequate seedling growth after grafting (SHARMA et al., 2019; CAMPOS et al., 2017), which may impose the need to use larger-diameter rootstocks. In the present study, rootstocks with diameter between 3.68 to $5.5 \mathrm{~mm}$ provided satisfactory vigour and reduced the time for seedling formation. This type of seedling, although less vigorous, can facilitate obtaining and also transporting from nursery to producer. In addition, earlier grafting could speed up the implementation of experimental orchards to evaluate new rootstocks under field conditions.
Seedlings showed similar behaviours regarding the relationship between height growth and stem diameter, with no indication of etiolation due to treatments (Figure 4A). A characteristic that can indicate seedling quality is the ratio between height and diameter of the plant stem. In general, seedlings that show greater height growth and lower thickness are considered of poor quality and are less likely of surviving in the field (CARNEIRO et al., 2007; PINTO et al., 2016). 


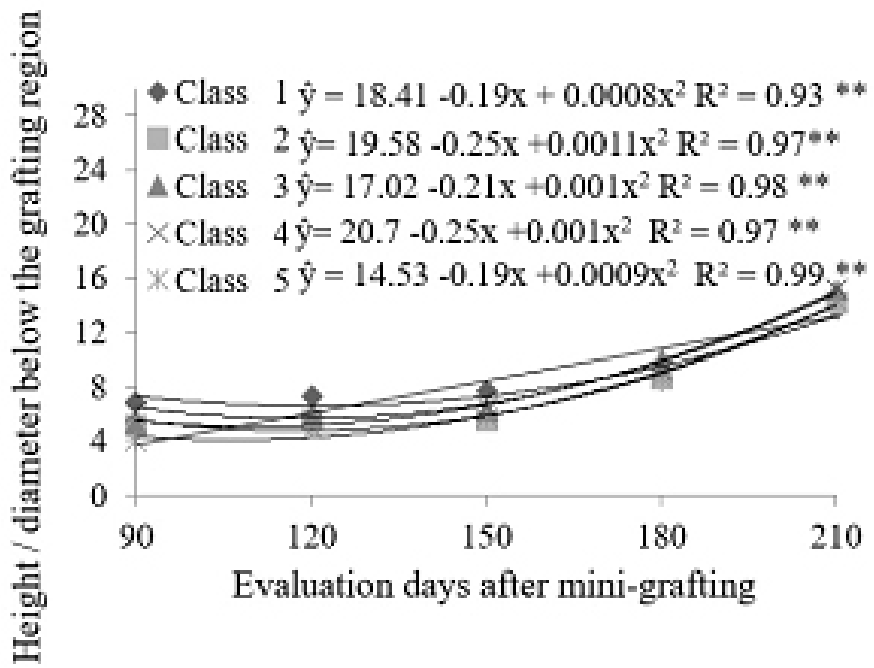

A

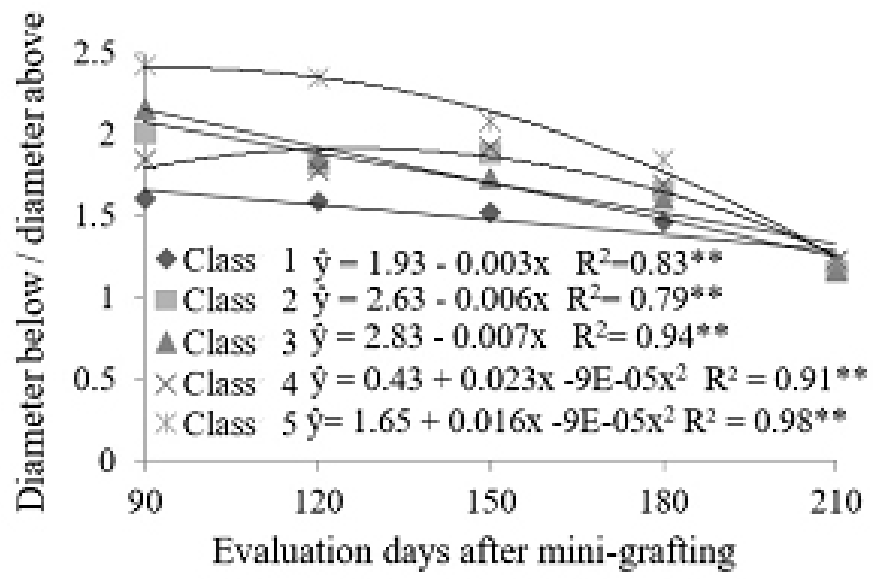

Figure 4. Polynomial regressions for ratios between height and diameter of 'Paluma' guava seedlings grafted by mini-grafting onto rootstocks of different diameter classes evaluated between 90 and 210 days after grafting (A). Polynomial regressions for ratios between diameter below and diameter above the grafting region of 'Paluma' guava seedlings grafted by mini-grafting onto rootstocks of different diameter classes evaluated between 90 and 210 days after grafting (B). ** Significant at 1\% probability. Rootstock diameter classes at the time of grafting: 1 (3.68 to 5.5 $\mathrm{mm}) ; 2$ (5.51 to $6.5 \mathrm{~mm}) ; 3$ (6.51 to $7.22 \mathrm{~mm}) ; 4$ (7.23 to $7.74 \mathrm{~mm}$ ) and 5 (7.75 to $10.32 \mathrm{~mm}$ ).

At 210 days after mini-grafting, all treatments showed ratio between diameter below and above the graft approaching the unit, indicating that over time, mini-graft and rootstock diameters tended to be equal in all treatments (Figure $4 \mathrm{~B}$ ).

The use of smaller-diameter rootstock can anticipate the availability of seedlings for the formation of new orchards. The present work showed viability for obtaining rootstocks using herbaceous cuttings. The time required to obtain smaller-diameter rootstocks was 180 days after cutting. Campos et al. (2017) used seeds as a source of propagule for rootstocks and performed grafting 200 days after sowing. Robaina (2011) used seeds to obtain rootstocks and carried out top cleft grafting about 428 and 390 days after the sowing of araçai and guava, respectively. In the present work, the vegetative propagation of the rootstock by herbaceous cuttings associated with early grafting by mini-grafting provided grafting anticipation and seedling formation period that could be obtained at 300 days after rootstock cutting.

In the case of the development of hybrid rootstocks resistant to $M$. enterolobii, rootstock propagation must be carried out vegetatively, so that the resistance of the genetic material is not lost. In this sense, preliminary rootstock propagation by herbaceous cuttings and subsequent grafting by mini-grafting is a proposal to obtain seedlings with genetic fidelity both of scion and rootstock under better nutritional and phytosanitary management conditions. 


\section{Conclusion}

Vegetative rootstock propagation by herbaceous cuttings associated with grafting by mini-grafting on rootstocks with diameter between 3.7 to $5.5 \mathrm{~mm}$ provides the anticipation of grafting and seedling formation period, which can be obtained at 300 days after rootstock cutting.

\section{Acknowledgments}

The authors would like to thank the Research Support Foundation of the State of Rio de Janeiro (FAPERJ) for the financial assistance and the Coordination for the Improvement of Higher Education Personnel (Capes) and CNPq for scholarships granted to carry out this study.

\section{References}

ALTENDORF, S. Minor tropical fruits: mainstreaming a niche market. Roma: FAO, 2018. p.67-74. Disponível em: www.fao.org. Acesso em: 30 mar. 2020.

ABBAS, M.M.; JAVED, M.A.; ISHF, A.Q.M.; ALVI, M.A. Grafting techniques in guava (Psidium guajava). Journal of Agricultural Research, Washington, v.51, n.4, p.465471, 2013.

BIAZATTI, M.A; MARINHO, C.S; ARANTES, M.B.S; GUILHERME, D.O. Multiplication of cattley guava by different techniques and variability among genotypes in vigor and rooting. Cerne, Lavras, v.24, n.4, p.379-386, 2018 .

BIAZATTI, M.A.; SOUZA, R.M; MARINHO, C.S.; GUILHERME, D.O; CAMPOS, G.S.; GOMES, V.M.; BREMENKAMP, C.A. Resistência de genótipos de araçazeiros a Meloidogyne enterolobii. Ciência Rural, Santa Maria, v.46, n.3, p.418-420, 2016.

CAMPOS, G.S.; MARINHO, C.S.; PORTELLA, C.R.; AMARAL, B.D.; CARVALHO, W.S.G. Production of guava mini-grafted on intra or interspecific rootstock. Revista Brasileira de Fruticultura, Jaboticabal, v.39, n.1, p.e-635, 2017.

CARNEIRO, R.M.D.G.; MOREIRA, W.A; ALMEIDA, M.R.A.; GOMES, A.C.M.M. Primeiro registro de Meloidogyne mayaguensis em goiabeira no Brasil. Nematologia Brasileira, Brasília, DF, v.25, n.2, p.223228, 2001.
CARNEIRO J.G.A.; BARROSO D.G.; SOARES L.M.S. Crescimento de mudas em raiz nua de Pinus taeda, L.produzidas em cinco densidades no viveiro. Scientia Agricola, Piracicaba, v.64, n.1, p.23-29, 2007.

CASTRO, J.M.C. Meloidogyne enterolobii e sua evolução nos cultivos brasileiros. Informe Agropecuário, Belo Horizonte, v.40, n.306, p.41-48, 2019.

COSTA, A.F.S.; COSTA A.N. Tecnologias para produção de goiaba.Vitória: INCAPER, 2003. 341p. Disponível em: http://biblioteca.incaper.es.gov.br/. Acesso em: 15 set. 20 .

COSTA, S.R.; SANTOS, C.A.F.; CASTRO, J.M.C. Assessing Psidium guajava $\times$ P. guineense hybrids tolerance to Meloidogyne enterolobii. Acta Horticulturae, Leuven, v.959, p.59-66, 2012.

FERREIRA, G.O.; NASCIMENTO, R.C.; COSTA, S.R.; NOGUEIRA, T.O.; SANTOS, C.A.F.; FLORI, J.E. Propagação vegetativa de plantas originadas do cruzamento entre Psidium guajava x Psidium guineense, resistentes a Meloidogyne enterolobii. In: JORNADA DE INICIAÇÃO CIENTÍFICA DA EMBRAPA SEMIÁRIDO, 8., 2013, Petrolina. Resumos [...] Petrolina: Embrapa Semiário, 2013. p.15-19.

GOMES, V.M.; SOUZA, R.M., MUSSI-DIAS, V.; SILVEIRA, S.F.; DOLINSKI, C. Guava decline: a complex disease involving Meloidogyne mayaguensis and Fusarium solani. Journal of Phytopathology, Berlin, v.159, n.1, p.45-50, 2011.

GOMES, V.M.; RIBEIRO, R.M.; VIANA, A.P.; SOUZA, R.M.; SANTOS, E.A.; RODRIGUES, D.L.; ALMEIDA, O.F.Inheritance of resistance to Meloidogyne enterolobii and individual selection in segregating populations of Psidium spp. European Journal of Plant Pathology, Wageningen, v.10, p.345-350, 2017.

HARTMAN, H.T.; KESTER, D.E.; DAVIES, F.T.; GENEVE, R. Plant propagation: principles and pratice. $8^{\text {th }}$ ed. Essex: Pearson New International Edition, 2013. $928 \mathrm{p}$.

PEREIRA, F.M.P.; USMAN, M.; MAYER, N.A.; NACHTIGAL, J.C.; MAPHANGA, O.R..; WILLEMSE, S. Avanços na propagação da goiabeira. Revista Brasileira de Fruticultura, Jaboticabal, v.39, n.4, p.e-358, 2017.

PINTO, A.V.F.; ALMEIDA, C.C.S.; BARRETO, T.N.A.; SILVA, W.B.; PIMENTEL, D.J.O. Efeitos de substratos e recipientes na qualidade das mudas de Tabebuia aurea (Silva Manso) Benth.\& Hook.F.Ex S.Moore. Revista Biociências, Taubaté, v.22, n.1, p.100-109, 2016. 
ROBAINA, R.R., CAMPOS, G.S., MARINHO, C.S., SOUZA, R.M., BREMENKAMP, C.A. Grafting guava on cattley guava resistant to Meloidogyne enterolobii. Ciência Rural, Santa Maria, v.5 n.9, p.1579-1584, 2015.

ROBAINA, R.R. Enxertia de copa e subenxertia entre a goiabeira 'Paluma'(Psidium guajava l.) e araçazeiros (Psidium cattleyanum) visando á produção de mudas resistentes a Meloidogyne enterolobii. 2011. Dissertação (Mestrado em Produção Vegetal) o Centro de Ciências e Tecnologias Agropecuárias da Universidade Estadual do Norte Fluminense Darcy Ribeiro, Campos dos Goytacazes, 2011.

VELOSO, J.S.; CÂMARA, M.P.S.; SOUZA, R.M. Guava decline: updating its etiology from 'Fusarium solani' to Neocosmospora falciformis. European Journal of Plant Pathology, Dordrecht, v.158, n.4, p.1-6, 2020.

SHARMA, M.K.; BHAT, R.; NAZIR, N.; KHALIL, A.; SIMNANI, S.A.; SUNDOURI, A.S. Influence of rootstocks on scion growth and vigour, production, water relations, physiology and leaf nutrient status of temperate fruit crops- a review. International Journal of Current Microbiology and Applied Sciences, New Delhi, v.8, n.2, p.1089-1104, 2019.
SINGH, G.; GUPTA, S.; MISHRA, R.; SINGH, A. Technique for rapid multiplication of guava (Psidium guajava L.). Acta Horticulturae, The Hague, v.735, n.1, p.177-183, 2007.

SOUZA, R.R.; SANTOS, C.A.F.; COSTA, S.R. Field resistance to Meloidogyne enterolobii in a Psidium guajava x P.guineense hybrid and its compatibility as guava rootstock. Fruits, Leuven, v.73, n.2, p.118-124, p.2018.

SOMKUWAR, R.G.; TAWARE, P.B.; BHANGE, M.A.; SHARMA, J.; KHAN, I. Influence of different rootstocks on growth, photosynthesis, biochemical composition, and nutrient contents in 'fantasy seedless' grapes. International Journal of Fruit Science, Binghamton, v.15, n.3, p.1-16, 2015.

ZONTA, E.P.; MACHADO, A.A. SANEST: sistema de análises estatísticas para microcomputadores. Pelotas: UFPel, 1984. 75p. 